\title{
Spinal Cord Swelling in Multiple Sclerosis
}

\author{
THOMAS E. FEASBY, DONALD W. PATY, GEORGE C. EBERS, ALLAN J. FOX
}

SUMMARY: Three cases of subacutely progressive spinal paraparesis had myelographic evidence of spinal cord swelling suggesting the diagnosis of intramedullary tumour. The diagnosis of multiple sclerosis (MS) was made in each case with the aid of CSF protein electrophoresis, evoked responses and CT scan. Because acute $M S$ may produce cord swelling simulating tumor or syrinx, these additional investigations may be necessary to make a correct diagnosis.

RESUME: Trois cas de paraparésie spinale progressive sugaigus eurent à la myélographie des signes de dilatation de la moëlle, suggérant le diagnostic de tumeur intramédullaire. Cependant dans chaque cas. le diagnostic de sclérose en plaques (SEP) fut confirmé grâce à l'électrophorèse des protéines du LCR, aux potentials évoqués el à la lomodensitométrie. Parce que la SEP aigue peut causer un gonflement de la moëlle simulant une tumeur ou une syringomyélie, ces investigations supplémentaires peuvent s'avérer nécessaires pour confirmer le diagnostic.

From the Department of Clinical Neurological Sciences and the Department of Diagnostic Radiology. University Hospital, London, Ontario, Canada.

Reprint requests to: Dr. Thomas E. Feasby, Depart ment of Clinical Neurological Sciences, University Hospital, P.O. Box 5339, Postal Station A. London, Ontario, Canada N6A SAS.

\section{INTRODUCTION}

In progressive spinal cord disease, the myelographic finding of an enlarged spinal cord suggests a diagnosis of an intramedullary mass lesion such as a syrinx or tumor rather than an inflammatory myelopathy such as multiple sclerosis (MS). We have recently observed three cases of subacute myelopathy in which a swollen cord at myelography erroneously suggested an intramedullary tumor. Further investigations and clinical evolution led to a diagnosis of inflammatory myelopathy secondary to multiple sclerosis.

\section{CASE REPORTS}

Case 1 . This 37 year old woman (Case 1789-81) first noticed "heaviness" in her right leg and hip on August 28, 1979. The next day this sensation gradually involved her left leg and extended up to her left breast. The sensory disturbance fluctuated for three weeks until September 24 when she awakened with weakness in both legs, more marked on the right. The weakness progressed over two days so she could not walk without support. There was no bladder disturbance or back pain. She had no previous neurologic symptoms. Examination on September 26 showed a spastic increase in tone in both legs with marked bilateral weakness, increased leg reflexes, bilateral clonus and upgoing toes. Vibration and position sense were impaired below the knees. A metrizamide myelogram showed enlargement of the spinal cord at T3-4 (fig. 1). The spinal fluid had $140 \mathrm{wbc} / \mathrm{s} / \mathrm{cu}$. $\mathrm{mm}$, protein of $65 \mathrm{mg} / \mathrm{dl}$ and $\mathrm{IgG}$ of 8.2 $\mathrm{mg} / \mathrm{dl}$ and the protein electrophoresis showed oligoclonal banding. There was an abnormal auditory evoked response bilaterally and a delayed pattern-reversal visual evoked response from the right eye. A CT scan showed a low density enhancing lesion in the deep left frontal region in the periventricular area. By October 9 she began to show improvement in leg strength. A myelogram repeated on
October 18 showed that the cord was still enlarged at T3-4, but it was slightly reduced in size from the previous myelogram. By November 21 she was able to walk with one cane.

Case 2. This 35 year old woman (Case 16-97-99) awoke on May 1, 1979 with numbness and dysesthesia of her right trunk between her breast and waist. Two weeks later the altered sensation gradually extended to involve the right buttock, leg and perineum and she began to drag her right leg. She had no previous neurologic symptoms. Examination on May 30 showed a bilateral spastic increase in tone in her legs with mild right ankle dorsiflex or weakness, increased right knee and ankle jerks and a right upgoing toe. She had hypalgesia below T6 bilaterally with sacral sparing on the left and reduced vibration and position sense below the right knee. A metrizamide myelogram on May 31 showed symmetrical enlargement of the spinal cord from T3 to T5 (fig. 2). Dexamethasone $10 \mathrm{mgs}$ q.i.d. was begun on June 3 and, on June 4, a laminectomy was performed from T4 to T6. The cord appeared normal and small biopsies revealed only minimal evidence of gliosis. The spinal fluid contained 4 mononuclear cells and had a protein of $22 \mathrm{mg} / \mathrm{dl}$ and the protein electrophoresis revealed oligoclonal banding. Auditory and pattern-reversal visual evoked responses were normal. She showed gradual improvement in strength and sensation over the next six months.

Case 3. In 1971 this 44 year old woman (Case 04-95-64) developed aching in the left popliteal fossa and calf plus numbness of the right lateral calf, medial thigh and perineum over ten days. One year earlier she had had intermittent symptoms of visual blurring and girdle-like sensations affecting T8 and T12 bilaterally. Examination revealed bilateral abducting nystagmus, slightly increased tone in both legs and reduced sensation to pin prick, temperature and light touch below T3 on the right. She had hyperactive reflexes in her legs and her left toe was upgoing. Abdominal reflexes were absent. An oil myelogram showed widening of the spinal cord from $\mathrm{C} 2$ to $\mathrm{T} 2$. The spinal nuid taken at myelography had 

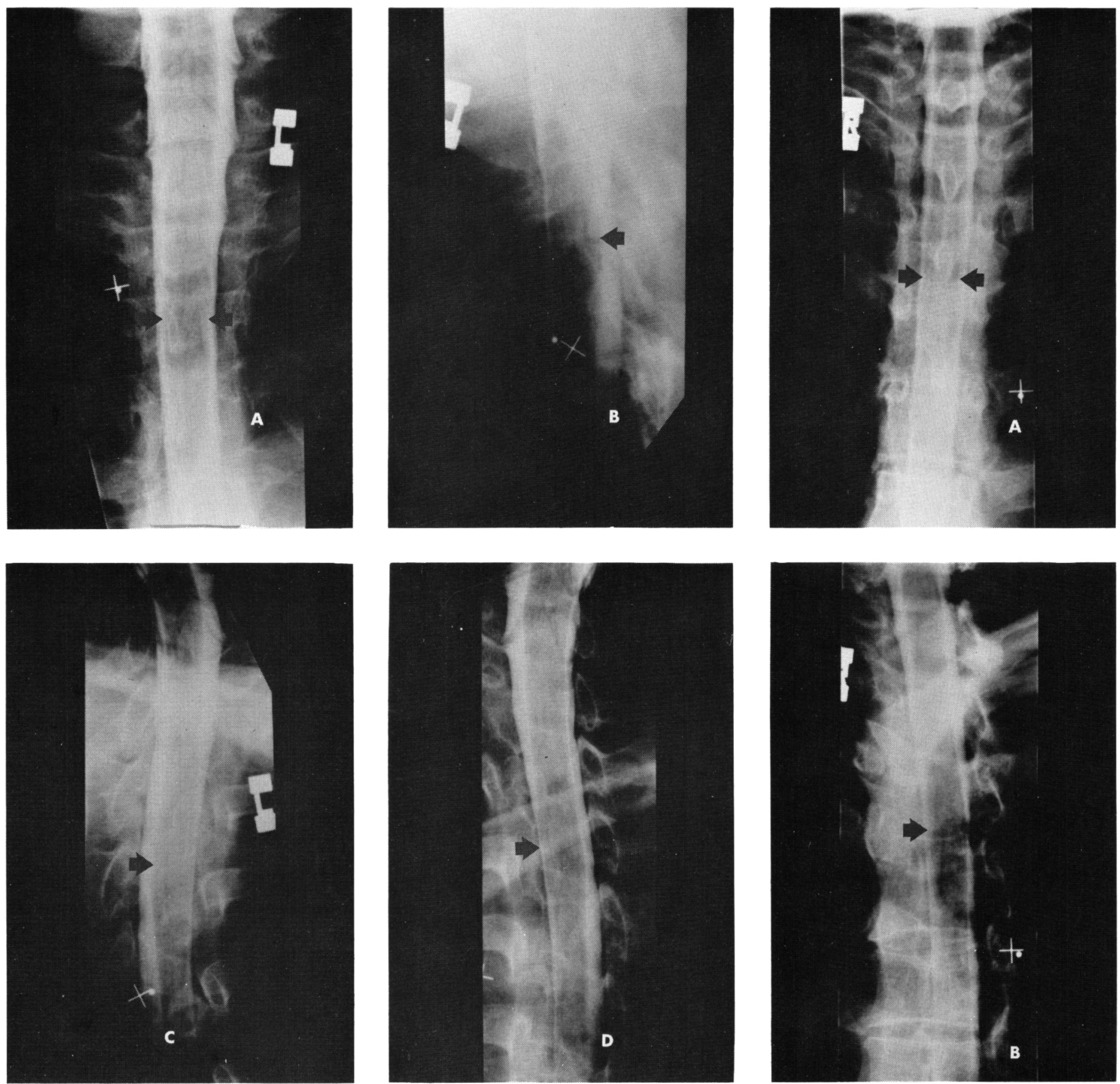

Figure I - Metrizamide myelogram of Case 1. (A) AP view shows enlargement of the cord shadow (arrows) with concomitant thinning of the lateral gutters at the T-4 level (B) Lateral view confirms cord enlargement at the same level (arrow). (C) \& (D) Oblique views show the cord enlargement at best advantage (arrow).

Figure 2 - Metrizamide myelogram of Case 2. (A) AP view shows enlargement of the cord shadow between T-3 and T5 , maximal at T-4 (arrows). (B) Oblique view similarly shows the cord enlargement (arrow), present as well on the other projection (not shown).

a protein of $30.5 \mathrm{mg} / \mathrm{dl}$ with no cells. She made a gradual recovery over several weeks. In the next eight years she had various episodes of neurologic dysfunction including right optic neuritis, right hemiparesis, bilateral leg pains and right hemianaesthesia. In January 1975 her spinal fluid examination showed 12 mononuclear cells and the protein electrophoresis revealed oligoclonal banding. In November 1978 the pattern-reversal visual evoked responses were delayed in each eye.

\section{DISCUSSION}

We have demonstrated spinal cord swelling in three patients with MS. As described by Charcot (1877), MS plaques can be swollen in the acute 
stage because of edema (Adams, 1977). This is compatible with the radiological finding that the acute cord swelling of MS subsequently subsides (Case 1) (Haughton et al, 1979). A pseudotumorous form of MS with marked plaque swelling in the spinal cord has been described (Herrmann and Jacob, 1968).

Although spinal cord swelling is seen occasionally in transverse myelitis (Altrocchi, 1963; Ropper and Poskanzer, 1978) and radiation myelopathy (Marty and Minckler, 1973), myelographic demonstration of spinal cord swelling in MS has seldom been reported (Haughton et al, 1979; Adams and Victor, 1977). Because the accepted clinical criteria for the diagnosis of MS (Schumacher et al, 1965) require clinical evidence of multiple lesions, an initial attack of myelopathy with cord swelling would not be diagnosed as MS. Alternatively, a new spinal cord lesion in a clinically established case of MS would not likely merit myelography. With modern diagnostic methods, particularly spinal fluid protein electrophoresis and evoked responses, it is often possible to make the diagnosis of multiple sclerosis at the first clinical episode (Paty, 1977) as in Cases 1 and 2. In addition, recent popular use of water-soluble contrast media (eg. metrizamide) may allow the demonstration of minor degrees of cord swelling which might not be detected using oil-based contrast. This is especially true in the thoracic region where metrizamide completely envelopes the cord filling the entire subarachnoid space (Valk, 1976).
In our two recent cases, (Cases 1 and $2)$, the clinical diagnosis of definite multiple sclerosis could not be made at the time of myelography. However, in both cases spinal fluid protein electrophoresis was performed using the fluid taken at myelography and oligoclonal banding, the pattern characteristic of MS (Paty et al, 1978) was found. This, together with the finding of other lesions in the nervous system on CT scan and visual and auditory evoked responses in Case 1, confirmed the diagnosis of MS. Although it might be argued that the diagnosis of MS in these cases remains in doubt based on accepted clinical criteria (Schumacher et al, 1965), the finding of oligoclonal banding is strong evidence for the diagnosis. The protein electrophoresis in 1000 consecutive CSF specimens from this center (Ebers and Paty, 1980) revealed oligoclonal banding in $92.8 \%$ of MS patients and in only 36/414 other patients. In 12 cases of spinal cord tumor or arteriorvenous malformation in that study plus three subsequent cases, oligoclonal banding has not been found.

The lesson to be learned from these cases is that because myelography may show spinal cord swelling in MS, alternative diagnostic measures, particularly spinal fluid protein electrophoresis and evoked responses, may be necessary to differentiate MS from intramedullary tumor and to avoid unwarranted surgical intervention.

\section{ACK NOWLEDGEMENT}

This investigation was supported in part by a grant from the Physicians' Services Incorporated Foundation of Ontario.

\section{REFERENCES}

ADAMS, C.W.M. (1977). Pathology of multiple sclerosis: progression of the lesion. Br. Med. Bull., 33: 15-20.

ADAMS. R.D. and VICTOR. M. (1977). Principles of Neurology. McGraw-Hill Inc. p 472.

ALTROCCHI, P.H. (1963). Acute transverse myelopathy. Arch. Neurol, 9: 111-119.

CHARCOT, J.M. (1877). Lectures on the diseases of the nervous system. L.ondon, The New Sydenham Society.

EBERS, G.C., PATY, D.W. (1980). CSF electrophoresis in 1000 patients. Can. J. Neur. Sci. 7: 275-280.

HAUGHTON, V.M., HO, K.C. and BOE DECKER. R.A. (1979). The contracting cord sign of multiple sclerosis. Neuroradiology, 17: 207-209.

HERRMANN, E. and JACOB. H. (1968), Multiple Sklerose mit pseudotumoralem Verlauf Zur Klinik und Neuropathologie. J. Neur. Sci. 7: 1-13.

MARTY. R.. MINCKLER, D.S. (1973). Radiation myelitis simulating tumour. Arch. Neurol. 29: 352-354.

PATY. D.W. (1977). Multiple Sclerosis: recent advances in diagnosis, clinical immunology and virology. Can. Med. Assoc. J. 117: 11,3114.

PATY, D.W., DONNELI.Y, M. and BERNARDO. M.E. (1978). CSF electrophoresis: an adaption using cellulose acetate for the identification of oligoclonal banding. Can.J. Neur. Sci. 5: 297-299.

ROPPER. A.H. and POSKANZER, D.C. (1978). The prognosis of acute and subacute transverse myelopathy based on early signs and symptoms. Ann. Neurol. 4: 51-59.

SCHUMACHER, G.A., BEEBE, G. and KIBLER, R.F. et al. (1965). Problems of experimental trails of therapy in multiple sclerosis. Ann. N.Y. Acad. Sci. 122: 552-568.

VALK. J. (1976). Myelography with metrizamide. Medicamundi. 21: 164-177. 